in New Guinea and the off-lying islands and in Tasmania. As a commander, in charge of the Egeria, he spent the years $1890-94$ on surveys in Borneo, Hong-Kong, Singapore, and Malacea Strait. Promoted to captain in 1895 , he resumed sea service in 1896 in command of the Penguin, in which during the next three years he made a number of surveys in the North and South Pacific and on the Australian coasts. Among these was the well-known survey and borings at the Funafuti Atoll under the auspices of the Coral Reef Committee of the Royal Society in 1897. This was the end of his foreign service. During $1900-4$, in command of the Research, he carried out surveys mainly in Irish and Scottish waters.

In 1904 he succeeded Rear Admiral Sir William Wharton as hydrographer of the Navy. During his five years period of office he continued the large programme of surveys at home and abroad in the tradition of his predecessors ; one of the most notable was that of Scapa Flow with a view to its use as a fleet anchorage, a proposal first submitted to the Admiralty by Graeme Spence in 1812. By increasing and raising the status of the eivilian technical staff within the Hydrographic Department, Field greatly increased its capacity to utilize for British hydrographic publications the results of foreign hydrographic surveys which had steadily grown in number and quality since the end of the nineteenth century. Subsequent needs in the First World War amply vindicated his vision.

Field wrote easily and with clarity. He contributed numerous articles on hydrographic surveying, its methods and apparatus to various scientific journals and the "Encyclopedia Britannica" (tenth edition). He revised and enlarged Wharton's famous original work "Hydrographic Surveying" for the third and fourth editions in 1909 and 1920 . He was elected a fellow of the Royal Society in 1905 and made K.C.B. in 1911.

After vacating the post of hydrographer of the Navy, Field served as Admiralty representative on the Port of London Authority during 1909-25, as acting conservator of the River Mersey 1910-30 and as nautical assessor to the House of Lords. In his private life he took a great interest in the problems concerning science and religious dogma, and he maintained an active correspondence with a number of theologians pressing for changes in doctrine which would admit many more men of science into the Anglican Church.

$$
\text { G. B. S. }
$$

\section{Dr. R. V. Norris}

Dr. Roland Vrotor Norris died at Port Shepstone, South Africa, on April 28, at the age of sixtytwo. He went to South Africa in November 1949 on holiday, and was due to return to the Tea Research Institute of Ceylon, of which he had been director since 1929. His death is a sad loss to the Institute he served so well, and a personal misfortune to his many friends, among whom may be included the whole of his staff.

After graduating from the University: of Manchester, Dr. Norris became private assistant to Prof. W. H. Perkin. Moving to the Lister Institute of Preventive Medicine, London, in 1910, he joined Prof. Arthur Harden's school and took part in the classical researches on the mechanism of alcoholic fermentation by yeast enzymes, for which work he was eventually awarded the D.Sc. degree of the
University of London. In 1912, while at the Lister Institute, he was elected to a Beit Memorial fellowship.

Dr. Norris's long career in the East began in 1914, when he accepted the post of physiological chemist at the Imperial Bacteriological Laboratory in India. His first administrative experience was gained in the Indian Army, in which his administrative abilities were soon recognized after a brief period of active service in 1915. From 1918 onwards, Dr. Norris gradually turned towards agricultural research, first becoming agricultural chemist to the Government of Madras. When professor of biochemistry in the Indian Institute of Science, Bangalore (1924-29), his research students were largely occupied with biochemical problems relating to agricultural subjects such as soils, plants, manures, the lac industry and the spike disease of sandalwood.

In 1929 , Dr. Norris was appointed to the directorship of the Tea Research Institute of Ceylon, when the construction of the permanent quarters at St. Coombs was just starting. The Institute has grown from its foundation on St. Coombs Estate to its present status under his guidance, and will be a memorial to his industry so long as it exists.

'R. V.', as he was known to his colleagues, was by no means a pedant. He was a widely travelled and well-read man of many interests. He was actively interested in sports, particularly rugby and hockey, and took a full part in many social activities. In his later years he became keenly interested in freemasonry and achieved the rare distinction of occupying the chairs of two Lodges under the English Constitution and one under the Irish Constitution.

European, Indian and Singhalese colleagues of two generations, and many members of the tea industry, will remember 'R. V.' with affection. Having worked under his direction for sixteen years, I can pay tribute to his tolerant but firm direction, critical but staunch support, and his fatherly guidance and encouragement.

J. LAMB

\section{Dr. Otto A. Beeck}

Dr. Otтo A. BeEcK, associate director of research, Shell Development Co., California, died suddenly on July 5. He was born on October 21, 1904, in Stettin, Germany. He was educated in Europe, following which he was post-doctorate research fellow at the California Institute of Technology during 1930-33, serving also as instructor. He joined the Shell Development Co. at Emeryville, California, in 1933 and organised there a broad programme of fundamental research in physics and related aspects of chemistry. He became head of the newly created Physies Department in 1936 and was made an associate director in 1942.

Prior to joining the Shell Development Co., Dr. Beeck carried out research in gas discharges. Since then he has engaged in research on catalysis, the physics and chemistry of surface phenomena, the study of reaction mechanisms by tracer methods, and the fundamentals of lubrication. He was a member of the National Research Council's Committee on Catalysis and of the Sub-Committee on Lubrication, Friction and Wear of the National Advisory Com. mittee for Aeronautics. He was active also on the Advisory Couneil of the American Institute of Physics.

Dr. Beeck was interested in art, photography and ski-ing, and was an amateur farmer and horse fancier. 